\title{
Public-private partnership as the leadership composition of the development of industrial production
}

\author{
Vera Lebedeva \\ Odessa National Polytechnic University \\ Shevchenka Ave. 1, 65000, Odessa \\ Ukraine \\ e-mail: LebedevaV@ukr.net \\ Natalia Dobrianska \\ Odessa National Polytechnic University \\ Shevchenka Ave, 1, 65000, Odessa \\ Ukraine \\ e-mail: semen-198@te.net.ua \\ Larisa Gromova \\ Herzen State Pedagogical University of Russia \\ 48 Moyka Emb., 191186 Saint Petersburg \\ Russian Federation \\ e-mail: gromovala@herzen.spb.ru
}

\begin{abstract}
The development of industrial production through the transition to higher technological processes and the increase of efficiency of its management is a key task at the present stage of the functioning of the domestic economy. These circumstances give rise to the need to deepen the theoretical and methodological and applied principles of the formation of strategic imperatives for the development of industrial production, which are formed by the society, the state, the subjects of market interactions, and the development of qualitatively new, modern-day achievements, formal and informal institutional changes. All this necessitates a profound theoretical analysis of the essence and tendencies of the mechanism of realization of public-private partnership on the principles of project management, revealing the contradictions of public-private partnership that influence the development of industrial production. The article analyzes the current state of development of industrial production in Ukraine. The role of the state in ensuring the development of industrial production on the principles of functioning of the mechanism of public-private partnership is substantiated. The principles of forming a project management system for the formation and development of public-private partnership, a system of criteria for the formation of a partnership portfolio at the appropriate managerial levels have been identified. The phases of management and processes which are characteristic, in particular for the formation and implementation of concession projects of public-private partnership in Ukraine are determined. The necessity of creating a special project company for the management of projects for the formation and development of publicprivate partnership is pointed out. The algorithm of regulation of the realization of public-private partnership projects in ensuring the development of industrial production is proposed. The results of the study provide the opportunity to apply new practical methods in forming models of partnership between the state and the industrial sector to ensure a competitive economic development. The necessity of developing a complex applied mechanism for measuring the effectiveness of public-private partnership on the basis of project management, which would allow to design and implement measures in the direction of development of industrial production, as well as achievement of tactical and strategic competitive advantages in the world market, is substantiated.
\end{abstract}

\section{Introduction}

Effective development of industrial production in Ukraine is affected by a number of serious obstacles that require immediate resolution. The technological and technical backwardness of industrial production, the ineffectiveness of the activities of industry development institutes, the low turnover of capital and investment attractiveness, and high labor productivity indices necessitate the improvement of the management mechanism (Filipishyna et al. 2018). A group of scientists in the study of structural transformations in the national economy has proven and focused on a special place in the system of institutional support for structural adjustment of the national economy, which is related to the synergy of the elements of the institutional system (Mikhaylov 2018). Moreover, some scientists (see e.g. Pavliuk and Pavliuk 2010; Janda et al. 2013; Kuzmin et al. 2015; Vasylchak and Halachenko 2016; Oláh et al. 2017; Būmane 2018; Naumov et al. 2018; or Orlova et al. 2018) managed to 
simulate the overall architecture of institutional support for structural adjustment of the economy, within which an important place is allocated to public-private partnership.

In a theoretical aspect, public-private partnership represents a model of institutional relations between the state and business with integrated functional responsibility and a flexible hierarchy in the economy of a market type. Under such an interpretation, as a rule, two meanings are understood. In the first case, it is a system of relations between the state and business in the contractual and treaty form, which is widely used as a tool for the regulation of socio-economic development, that is, an instrument for the institutionalization of this development (Abrhám et al. 2015a; 2015b; or Baimuratov et al. 2018). In the second case these are concrete projects that are implemented on the basis of different forms of ownership. Both this and other content disclose the subject of public-private partnership in terms of the effective use of the state or communal property in favor of the economic entity (Melnyk and Pidhaiets 2011).

According to Vlasov (2012), in the broad sense, the concept of "public-private partnership" includes all forms of cooperation between the state and the private sector, which are in the field of solving problems traditionally related to the competence of the state, the state itself, on the one hand, and the possible privatization on the other (Vlasov 2012). In the broad sense, public-private partnership can be interpreted as a system of relations between public authorities (management) and private organizations, in which private organizations are given a larger role in planning, financing and realization of certain services for the population, rather than using traditional procedures of cooperation (for example, a tender), and less than using the mechanism of privatization. At the same time, the protection of the state and communal interests is guaranteed through the institutional framework, the provisions of normative acts and concluded contracts (Vynnytskyi et al. 2008).

In spite of the attempt to clarify the composition of relations, in the above mentioned definitions there are, in our opinion, both the discussion clauses and the false interpretation of it. It is erroneous to assume that publicprivate partnership is different, or any interaction between the state and business, which does not require special institutional and organizational support, that public-private partnership is a strengthening of the system of management exclusively by tangible assets and objects. We also agree with the opinion of Kuzminov that the approach is wrong when the state in public-private partnership can get socially significant objects and, with their help, provide services to the society, without spending money and risking nothing (Kuzminov 2014) . In addition, it is believed that the development of public-private partnership does not require competent and specially competent employees, both at the state and at the municipal levels, accordingly, investments in their training are not taken into account. One can also agree with the opinion that in many definitions there are no signs that any real projects with the participation of the state and private capital can or can not be attributed to public-private partnership (Danko et al. 2015; Moskalenko and Yevsieieva 2015).

Taking into account the foregoing, we believe that public-private partnership, based on a certain legal basis, is the cooperation of the state, private sector entities of the economy and public institutions in various socio-economic spheres of activity for the implementation of significant public and priority projects for the state, for its political and institutional support, the pooling of resources of the parties, the equitable sharing of risks between partners, transparency and equality of relations to ensure the effective development of the industrial production (see e.g. Kindersky 2010; Vyshnevsky et al. 2013; Heiets, 2014; Gryshova 2015; Chamberlin 2015; Naumov and Stoianova-Koval 2016; Baimuratov et al. 2018; or Gryshova 2018).

Despite the development of theoretical and methodological provisions regarding the essential characteristics of the public-private partnership, its evolution, models of application, in the economic literature insufficient attention is paid to the implementation of the mechanism of public-private partnership in the institutional architecture of the development of industrial production. The conceptualization of its participation in the institutional provision of the development of industrial production on the principles of project management has not been sufficiently highlighted and is relevant today.

The purpose of the study is theoretical substantiation and development of scientific and practical recommendations on the modernization of the mechanism of public-private partnership in the system of institutional architecture of the development of industrial production on the principles of project management. In accordance with the objective of the study, the following tasks have been identified and solved: - to substantiate the conceptual foundations of the improvement of the mechanism of public-private partnership as an institutional component of the development of industrial production on the principles of project management; to develop the algorithm of regulation of the process of implementation of public-private partnership projects in ensuring the development of industrial production.

\section{Materials and methods of research}

In the process of research, general scientific and special research methods were used, in particular: theoretical generalization, comparison and morphological analysis - in the process of formation of the conceptualcategorical apparatus of the research; system analysis - for the formation of conceptual foundations of the project management system for the formation and development of public-private partnership, identification of its main 
elements in the institutional provision of the development of industrial production; comparative analysis - in identifying the differences, positive and negative sides of the mechanisms of partnership of the state and industrial production and the main barriers for its further development; statistical analysis - for studying, grouping, comparison of empirical data in order to study the state of development of industrial production in Ukraine; economic and mathematical method - for construction of the algorithm of regulation of the realization of public-private partnership projects in ensuring the development of industrial production; regulatory-legal monitoring - to assess the compliance of the institutional environment with the conditions for the development of public-private partnership.

\section{Results and discussions}

The processes taking place in the domestic industry in the last two decades do not coincide with the global trends, despite the fact that the Ukrainian economy has become closely integrated into the world economy during this period. As in the world, the contribution of domestic industry to the creation of added value in comparison with other types of economic activity decreases annually, giving way to the services sector. In 2015, it amounted to $22.0 \%$, whereas in 2001 it was $33.1 \%$, with the decrease being due to the processing industry, whose share declined almost twofold, from 21.3 to $11.2 \%$, while the indicator for the extractive industries increased from $4.9 \%$ in 2001 to $5.4 \%$ in 2015 .

In the dynamics of industrial production during 1991-2016, consecutive cyclic waves with appropriate stages decay, depression, recovery and growth can be traced (Figure 1).

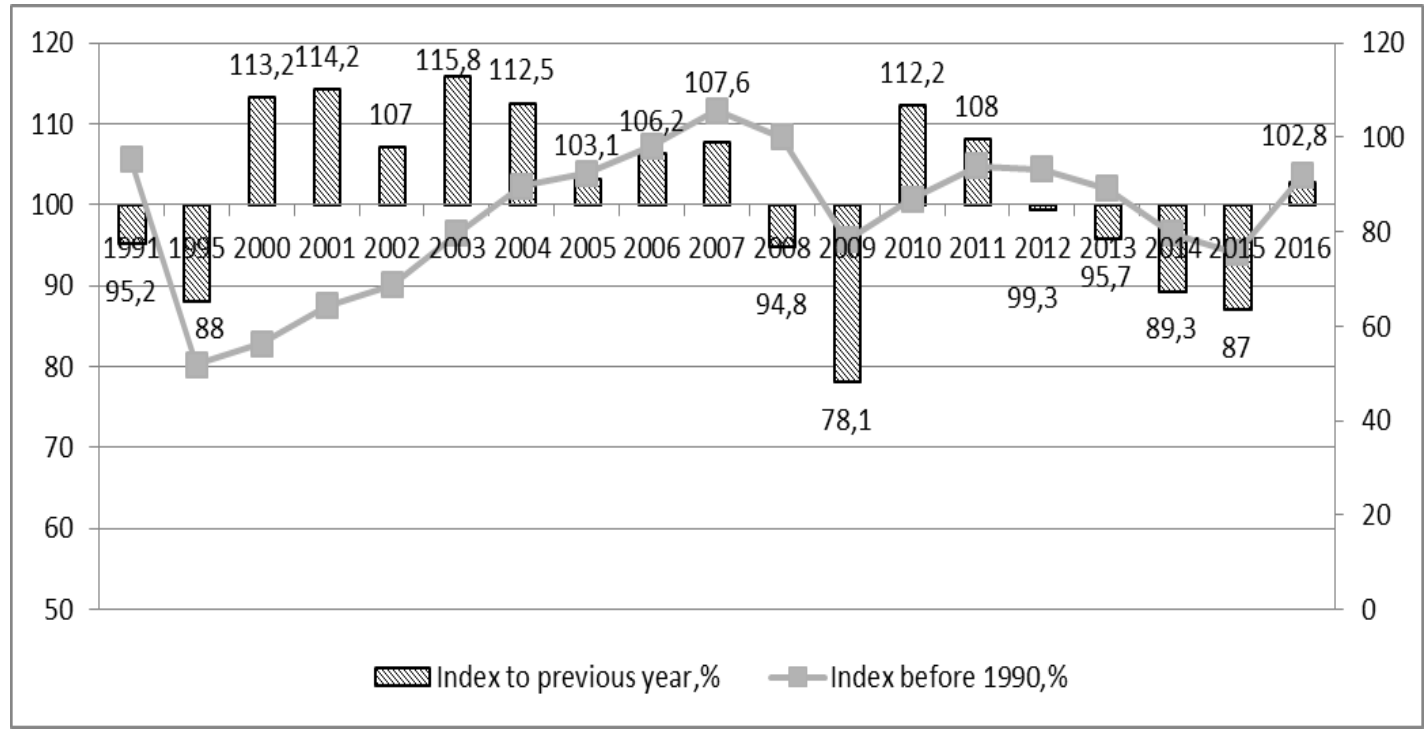

Fig. 1. Dynamics of indices of industrial production in Ukraine for 1991-2016. Source: Own results

The reorientation of domestic production to the needs of the domestic market is an important, but insufficient condition for improving the sectoral structure of industry. In Ukraine, the domestic market, due to its commodity structure and, accordingly, the structure of domestic consumption, is a significant limiting factor for the progressive restructuring of production. Although during the 2001-2016 period, the structure of the domestic market has changed in the direction of increasing the tone of consumption, but not so much as to drastically affect the change in the structure of domestic production, especially taking into account the growing satisfaction of domestic demand through imports.

The basis of the development of industrial production is the state of its innovation and investment activity. The data in Table 1 give reason to assert that during 2010-2016 the investment of industrial production decreases and the development of innovation processes is slowed down. In 2016, 85\% of the costs of enterprise innovation were funded independently. Therefore, a vital task for Ukraine is the development and implementation of a system of measures to stimulate investment attraction and intensification of innovation processes in industry. If the state does not create programs to support the innovative activity of enterprises, Ukraine's industrial production may become technically outdated and uncompetitive.

The main tasks in the context of the development are innovation and technological restructuring of industrial production, the improvement of mechanisms of attraction and effective use of investment resources, 
obtaining the synergy effect of interaction between the state and the industrial sector, ensuring a clear target orientation of investment processes and consolidated funds of the state and the industry.

Table 1. Dynamics of indicators of innovation and investment activity of the industry of Ukraine for 2010-2016

\begin{tabular}{|l|c|c|c|c|c|c|c|}
\hline \multicolumn{1}{|c|}{ Indexes } & 2010 & 2011 & 2012 & 2013 & 2014 & 2015 & 2016 \\
\hline $\begin{array}{l}\text { The volume of capital } \\
\text { investments into industry of } \\
\text { Ukraine, mln.UAH. }\end{array}$ & 59240 & 85432 & 102843 & 103346 & 83476 & 72167 & 75269 \\
\hline $\begin{array}{l}\text { The share of capital } \\
\text { investments in Ukrainian } \\
\text { industry, \% }\end{array}$ & 30,0 & 34,30 & 35,23 & 39,44 & 39,30 & 38,40 & 39,20 \\
\hline $\begin{array}{l}\text { Direct foreign investments in } \\
\text { the industry of Ukraine, mln. } \\
\text { USD }\end{array}$ & 13756 & 14265 & 14957 & 17378 & 18934 & 14988 & 13647 \\
\hline $\begin{array}{l}\text { The share of direct foreign } \\
\text { investments in the industry of } \\
\text { Ukraine, } \%\end{array}$ & 33,2 & 30,09 & 29,6 & 30,7 & 31,7 & 32,3 & 31,4 \\
\hline $\begin{array}{l}\text { New technological processes } \\
\text { introduced in the industry of } \\
\text { Ukraine, units }\end{array}$ & 2380 & 2450 & 2270 & 1860 & 2130 & 2080 & 2115 \\
\hline $\begin{array}{l}\text { Production of innovative } \\
\text { types of industrial products } \\
\text { introduced in Ukraine, units }\end{array}$ & 2420 & 2540 & 2685 & 2534 & 2760 & 2640 & 2820 \\
\hline $\begin{array}{l}\text { The share of industrial } \\
\text { enterprises that introduced } \\
\text { innovations in the industry of }\end{array}$ & 11 & 12,8 & 13,3 & 13,2 & 12,0 & 12,4 & 12,7 \\
Ukraine, \% & & & & & & & \\
\hline $\begin{array}{l}\text { The share of implemented } \\
\text { innovative industrial output } \\
\text { outside Ukraine in the total } \\
\text { volume of realized innovative } \\
\text { products in Ukraine, } \%\end{array}$ & 40,7 & 29,8 & 36,9 & 44,8 & 29,17 & 27,5 & 28,2 \\
\hline
\end{tabular}

Source: Own results

It is determined that innovation activity in industrial production needs system modernization in the context of creating institutional conditions for a qualitatively new model of innovation process, which should be formed on a market-competitive basis, combining market mechanism with state regulation. In a market economy, the main institutions of innovation activity are: 1) business entrepreneurship, since it is in it that not only economic interests and motives are formed, but also potential opportunities (intellectual, financial, resource) for the creation and introduction of innovations are realized; 2) scientific organizations that expand existing knowledge and form innovative development on their basis; 3) the state that fully stimulates and supports the development of innovation activities. The interaction of these institutes generates appropriate institutional conditions characterized by a certain set of rights, obligations and restrictions related to management, finance and employment (Naumov and Stoianova-Koval 2016).

In view of this, the issue of forming a project management system for the formation and development of public-private partnership becomes relevant. By and large, any managerial decisions on the development of industrial production can be implemented as national (sectoral, regional) projects. The decision to solve the problems of the development of industrial production on the principles of combination of efforts of power and business can be considered as projects of formation and development of partnerships, and the mechanism of implementation of these decisions as a mechanism of managing the projects (the mechanism of project management).

However, in modern conditions, there are some limitations for using the mechanism of public-private partnership on the principles of project management, in particular: the industrial sector is not always interested in taking up projects due to high risks and complexity of projects; the transfer of ownership of state objects, such as infrastructure, to the industrial sector does not always lead to an increase in the efficiency of their functioning. This is often due to serious reforms in the industry or the market as a whole and changes in management practices; the success of public-private partnership projects depends on the high management efficiency, the achievement of which is a complex process under the influence of many factors (Gryshova and Shestakovska 2017).

Traditionally, the management of projects refers to the sphere of management that covers those areas of the state, local government, industry in which the creation of a product and services is carried out as a unique set of interrelated measures in the presence of certain restrictions: the term, budget or expected result. 
Public-private partnership projects are usually endowed with specific features that involve the state as a lead partner in the project, defining certain partnership frameworks, such as: different legal status of partners; peculiarities of budget accounting; specific features of the decision-making system in the public sector (formal requirements to the decision-making process); differences in rules and regulations regarding public procurement and orders.

\section{Project management of public-private partnerships}

In our opinion, the following principles should be put into the basis of the mechanism for the formation of a project management system and the development of a public-private partnership:

1) the principle of diagnosing problems that require the unification of the efforts of power and industrial production;

2) the principle of harmonization of the interests of the parties;

3 ) the principle of achieving maximum discharges of budgets (state and local) in terms of expenditures for solving problems of economic and social development with the possibility of compensation by their industrial sector in the interests of the sides;

4) the principle of achieving the effect of synergy as a result of the interaction of partners;

5) the principle of mutual benefit and equality of partners;

6) the principle of trust;

7) the principle of scientific and legislative reinforcement.

The project management system for the formation and development of public-private partnerships in the institutional architecture of the development of industrial production can be represented as a targeted subjective action of the central and local executive authorities, local governments, subjects of industrial production with the definition of appropriate models and mechanisms of their implementation. The basis for its construction should be the principle of goal-setting (a clear definition of why, with what purpose, partnership projects should be created) who will act as the initiator of the partnership, what synergy effect is expected, what "value for money" or cost savings can be achieved. In other words, through the formation of a management system by the formation and development of partnership projects the problem of "failures" of the market and "failures" of the state sector regarding the institutionalization of the development of industrial production can be solved. In institutional terms, this requires the improvement of the legislative framework, taking into account the identified shortcomings and foreign practices, the abolition of the norms and restrictions that hinder these processes, the training of management personnel for the implementation of public-private partnerships, and the development of consulting (Kindersky 2010).

The ascent from the formation of a system for managing the formation and development of public-private partnership at the macro-meso-local level to the level of management of a particular project stems from the principle of systemicity and is due, first of all, to the fact that the lack of implementation of public-private partnership as a mechanism and component of institutional development of support of industrial production is due to the lack of adequate number of successfully implemented projects.

The mechanism of project management of public-private partnership is based on the following mechanisms, which are implemented at the level of industrial production: 1) planning (optimization of commercial and production cycles, etc.); 2) risk management; 3) distribution of costs and tax burden; 4) examination and monitoring; 5) insurance; 6) diagnostics of the possibilities of tax preferences; 7) material and technical support; 8) operational management; 9) definition of tariff policy and pricing policy; 10) stimulation (Gryshova et al. 2017; Melnyk and Pidhaiets 2011).

The complex projects of public-private partnership deserve particular attention. The complex publicprivate partnership projects are usually characterized by high levels of uncertainty associated with rapid technical, political changes, and also the changes in the environment. The traditional project management can not be applied in this case, since it proceeds from the certainty of the scale of the project and is based on previously expected results.

On the basis of the above mentioned facts, we believe that the focus should be made on the processes that require revision and improvement in the management of public-private partnership projects in Ukraine during the period of financial and economic insufficiency, and to identify the main factors affecting success at the main stages of implementation of the projects.

The evaluation of financial indicators deserves particular attention. Taking into account the specifics of the concession mechanism, the following criteria can be used to assess financial indicators: 1) the minimum size of the required subsidy from the state; 2) the maximum amount of concession payments; 3 ) the minimum period of the duration of the contract; 4) the minimum level of tariffs (Pavliuk and Pavliuk 2010).

The in our opinion, we need to complete, analysis at the stage of evaluation of proposals, but sometimes 
it can be made longer, after a satisfactory partner has been selected. In parallel, this assessment should be also carried out by the interested secondary stakeholders, namely, the creditors and subcontractors.

It is also important to note that if the state's goal while initiating a public-private partnership project is, for example, reducing public spending, then the most important is the financial criteria (for example, the minimum amount of subsidies). However, if the main task of the PPP project is to achieve the best quality of service for end-users, reduce tariffs, and increase the social effect, then most of the suggested industry proposals as for the future project should be valued predominantly in terms of minimum tariffs and penalties for lowering the quality of work. In particular, the experience of France shows that, as a rule, the matters of safety and environmental protection become the most significant while considering the submitted offers by economic entities.

The final choice of the partner as a result of all procedures leads to the fact that the subject of industrial production becomes the sole partner of the state for the implementation of the public-private partnership project, acquires a monopoly right, the protection of which is guaranteed by the state. Therefore, on the basis of the above mentioned facts, one should pay attention to the fact that the representatives of the state should pay particular attention to the choice of their partner, to create a clear, well-established institutional environment for the selection of applicants, while defining the criteria, mechanisms and rules of the tender in advance.

At the final stages of the development phase of the project and the beginning of financing by investors, in our opinion, the project company should be formed. The state may in some cases require the inclusion of local investors in the design company in order to develop and transfer experience and technology, which in the future may lead to the creation of new jobs and better skilled training of local staff. The project company should be located in the area of contractual and financial mutual relations in public-private partnership projects. In the case of a public-private partnership using project financing (often found and used successfully in foreign practice), private investors usually create a special project company (SPE) with limited responsibility, which concludes a contract with the concessionaire. This experience may be acceptable for Ukraine.

The relevance of the creation of the SPV is caused by the following factors: the possibility for sponsors under this scheme to finance the project on the terms of a limited right of recourse. The right to recourse (the right of a person who has fulfilled the obligations of another person to bring up the last one the request for reimbursement of expenses) granted to creditors and cohich is limited mainly or entirely to the assets of the project. The level of recourse on the assets of their owners is often referred to as sponsorship, which may include an obligation and cover unforeseen project costs at the expense of the entity's equity or allow getting a subordinated loan to cover over-expenses; the need to take into account the impact of problems that arise in other areas of business that is not related to the implementation of the public-private partnership project (Vlasov 2012; Heiets 2014).

The project management can be carried out on its own by the project company with the involvement of the management process of subcontractors after the financial closing. In this case one of the alternative control models can be applied. On the one hand, the project company may not have a permanent staffing, in other words, all key management activities - the construction, operational management and operation of subcontractors, but the monitoring and control over the activities of subcontractors and the preparation of financial statements in this case should be handed over to independent specialized companies. The only permanent component inherent in this management mechanism is the functioning of the board of directors.

In general, it can be noted that for the project company, in our opinion, it will be more important to maintain a small amount of the staff and give a large number of narrow functions to experienced organizations. This will greatly facilitate the process of communication and control for the state, and the leader of the project organization will become a public person, who, among other things, will also provide social support to the public-private partnership project. It is advisable to entrust the work of continuous control over subcontractors to an independent person rather than carry out this managerial function within the project company.

The proposed algorithm of actions for managing the formation and implementation of public-private partnerships under the mechanism of concession is the basis for institutionalization of the management of the formation and development of public-private partnership projects in industrial production, since in this context certain standardized decisions are set forth in Ukraine, defined by the center. This, in particular, concerns the Ukrainian practice of creating government management groups. This function at the universal and standardized level is provided by the department, which operates within the structure of the Ministry of Economic Development and Trade of Ukraine. Taking into account Ukrainian realities, in order to ensure qualitative work on the project, monitoring of their implementation from the state partner, it would be appropriate to envisage the involvement of specialists: 1) on general issues (economists, financiers, tariff regulation specialists, public procurement specialists, etc.); 2) from the industry specification (specialists in the energy sector, housing and communal services, health care, education, etc.); 3) from the territorial affiliation (inclusion of specialists of local self-government).

The proposed measures for improving the mechanism of realization of public-private partnership projects in the conditions of financial and economic insufficiency include: the achievement of the most elastic and soft responsive system of public-private partnership management, the creation of a state management working group, 
transparent and regular communications between the state and private partner, minimizing the deadline for processing applications. In order to ensure the effectiveness of the mechanism for the implementation of publicprivate partnerships for the development of industrial production, it is necessary to carry out a sequence of actions that are presented in the form of an algorithm of regulation.

Taking into account the above mentioned information, we consider that in general, improving the efficiency of management at all the stages of the formation and implementation of the public-private partnership projects for the development of industrial production can be achieved through the following measures: improving public access to the information about the project and the schemes of conducting the competition; the creation of individual sites, the Internet portals for attracting potential contributors to the competition (especially for medium and small projects); the creation of a full-fledged, functioning state management working group with an effective manager; presentation to the creditors who bear high financial costs in case of corruption abuses in the project, the possibility of conducting selective monitoring of the work performed with the involvement of external consultants, which will increase transparency and control in general, as well as reduce the level of corruption abuses.

In general, the proposed conceptual vision of solving the problem of formation and development of the public-private partnership on the principles of project management covers two main areas of the state participation in the development of industrial production: 1) macroeconomic regulation of economic processes and their institutionalization, oriented on the goals of strategic development; 2) regulatory policy focused on the state's influence on industrial production with a view of involving it in solving important problems of economic and social development of the country, on the one hand, in support of entrepreneurship, especially small ones, by including it in administrative, informational and other state resource.

\section{Conclusions}

Summing up the consideration of the problem, one can conclude that in the basis of the conceptual framework for building a management system for the formation and development of the public-private partnership the general principles of project management can be laid. At the same time managing complex, complicated projects with high level of uncertainty and rapid change of technological, political and other factors under the influence of the projects of the public-private partnership, requires significant changes in the algorithm of traditional project management, as well as the introduction of project evaluation due to the results and consequences of implementation for the state, industrial sector and end users.

The scientific novelty of the results is the conceptualization of the mechanism of the public-private partnership as an institutional component of the development of industrial production on the basis of project management and the development of an algorithm for the regulation of the implementation of the public-private partnership projects in ensuring the development of industrial production, which is aimed at achieving the most elastic responsive project management system of the state-private partnership, creation of a state management working group, transparent and regular communications between the state and industrial production. The practical significance of the results obtained is the ability to apply new practical methods in shaping the models of partnership between the state and the industrial sector to ensure the competitive development of the national economy. The prospects for further research are the development of an integrated application mechanism for measuring the effectiveness of the public-private partnership on the principles of project management, which would allow the design and implementation of measures in the direction of development of industrial production, as the well as achievement of tactical and strategic competitive advantages on the world market.

\section{References}

Abrhám J, Bilan Y, Krauchenia A, Strielkowski W (2015a) Planning horizon in labour supply of Belarusian small entrepreneurs. Economic Research-Ekonomska Istraživanja 28(1):773-787. doi:10.1080/1331677X.2015.1084238

Abrham J, Strielkowski W, Vošta M, Šlajs J (2015b) Factors that influence the competitiveness of Czech rural small and medium enterprises. Agricultural Economics-Zemedelska Ekonomika 61(10):450-460. doi: 10.17221/63/2015-AGRICECON

Baimuratov M, Gryshova I, Akhmetova I (2018) Leadership of Territorial Communities: Local and Global Factors. In: Strielkowski W, Chigisheva O (eds) Leadership for the Future Sustainable Development of Business and Education. Springer Proceedings in Business and Economics. Springer, Cham pp.179-188. doi: 10.1007/9783-319-74216-8_19 
Būmane I (2018). The methodology of the statement of comprehensive income and its impact on profitability: the case of Latvia. Entrepreneurship and Sustainability Issues 6(1):77-86. doi: 10.9770/jesi.2018.6.1(6)

Chamberlin G (2015) Coordinating Monetary and Fiscal Policies in the Open Economy. International Economics Letters 4(1):15-25. doi: 10.24984/iel.2015.4.1.2

Danko Y, Kostyuchenko N, Petrushenko Y, Smolennikov D (2015) Community-based approach to local development as a basis for sustainable agriculture: experience from Ukraine. International Journal of Agricultural Resources, Governance and Ecology 2:178-189.

Filipishyna L, Bessonova S, Venckeviciute G (2018) Integral assessment of developmental stability: cases of Lithuania and Ukraine. Entrepreneurship and Sustainability Issues 6(1):87-99. doi: 10.9770/jesi.2018.6.1(7)

Gryshova I (2015) Ukraine's positions in international ratings evaluation as a factor of its competitiveness. Economic Annals-XXI 5-6:24-27

Gryshova I, Voronzhak PV, Shestakovska TL (2017) The implementation of the principles of consumerism in the strategy of the development of business. Scientific Bulletin of Polissia 2(10):41-48.

Heiets V (2014) Instytutsiina obumovlenist innovatsiinykh protsesiv u promyslovomu rozvytku Ukrainy [Institutional Condition of Innovation Processes in Industrial Development of Ukraine]. Ukraine economy 12:419.

Janda K, Rausser G, Strielkowski W (2013) Determinants of profitability of Polish rural micro-enterprises at the time of EU Accession. Eastern European Countryside 19:177-217. doi: 10.2478/eec-2013-0009

Kuzmin E, Berdyugina O, Karkh D (2015) Conceptual Challenges of Observability for Transaction Sector in Economy. Mediterranean Journal of Social Sciences 6(4S3): 391-402. doi: 10.5901/mjss.2015.v6n4s3p391

Kuzminov YI (2014) State-private partnership: on the way to efficiency. http://www.hse.ru/lingua/en/news/recent/4016069.html Accessed 10 Aug 2018

Kindzerskyi Yu (2010) Ekonomichnyi rozvytok i transformatsiia promyslovoi polityky v sviti: uroky dlia Ukrainy [Economic development and transformation of industrial policy in the world: lessons for Ukraine] 5:415.

Mikhaylov AS (2018) Socio-spatial dynamics, networks and modelling of regional milieu. Entrepreneurship and Sustainability Issues 5(4):1020-1030. doi: 10.9770/jesi.2018.5.4(22)

Moskalenko V, Yevsieieva I (2015) Effective leadership conflict management in food technology enterprises. International Economics Letters 4(2):91-102. doi: 10.24984/iel.2015.4.2.4

Melnyk AF, Pidhaiets SV (2011) Derzhavno-pryvatne partnerstvo v systemi instytutsiinoho zabezpechennia ekonomichnykh protsesiv [Public-private partnership in the system of institutional provision of economic processes]. Bulletin of the Ternopil National University of Economics 1:7-19.

Naumov O, Gryshova I, Rozsa Z (2018) Leadership in Energy Efficiency of Agro-industrial Production: Regional Aspects. In: Strielkowski W, Chigisheva O (eds) Leadership for the Future Sustainable Development of Business and Education. Springer Proceedings in Business and Economics. Springer, Cham, pp. 579-590. doi: 10.1007/978-3-319-74216-8_58

Naumov OB, Stoianova-Koval SS (2016) Mekhanizm derzhavno-pryvatnoho partnerstva yak instrument stabilizatsii investytsiinoho protsesu [The mechanism of public-private partnership as a tool for stabilizing the investment process]. Scientific notes of the Institute of Legislation of the Verkhovna Rada of Ukraine 6:98-105.

Oláh J, Bai A, Karmazin Gy, Balogh P, Popp J (2017) The Role Played by Trust and Its Effect on the Competiveness of Logistics Service Providers in Hungary. Sustainability 9(12):2303. doi:10.3390/su9122303

Orlova L, Gagarinskaya G, Gorbunova Y, Kalmykova O (2018) Start-ups in the field of social and economic development of the region: a cognitive model. Entrepreneurship and Sustainability Issues 5(4):795-811. doi:10.9770/jesi.2018.5.4(7)

Pavliuk KV, Pavliuk SM (2010) Sutnist i rol derzhavno-pryvatnoho partnerstva v sotsialno-ekonomichnomu rozvytku derzhavy [The essence and role of public-private partnership in the socio-economic development of the state]. Scientific works of KNTU 17:10-19.

Vasylchak S, Halachenko A (2016) Theoretical basis for the development of resort services: regional aspect. International Economics Letters 5(2):54-62. doi: 10.24984/iel.2016.5.2.3 
Vishnevsky VP, Amosha AI, Zbarazskaya LA, Industrial policy and management of industrial development under conditions of systemic imbalances: conceptual foundations, 1st edn. (National Academy of Sciences of Ukraine, Institute of Industrial Economics, Kiev, 2013), 180 p.

Vlasov A (2012) The special way of Petersburg in the sphere of public-private partnership. http://www.konkir.ru/article.html?id=3772 Accessed 18 Aug 2018

Vynnytskyi B, Lendel M, Onyshchuk B, Sehvari P, Dosvid ta perspektyvy vprovadzhennia derzhavno-pryvatnykh partnerstv $v$ Ukraini ta zakordonom [Experience and prospects of implementation of public-private partnerships in Ukraine and abroad], 1st edn. (K.: "K.I.S.", Kiev, 2008), 146 p. 